\title{
Identification on Critical to Quality of Online Shopping Services Based on QFD
}

\author{
Chao Zhang \\ Zhengzhou University School of Management Engineering,Zhengzhou,China \\ 354251997@qq.com
}

Keywords: online shopping service quality; service blueprint; QFD; customer demand

\begin{abstract}
In order to improve the level of service quality of online businesses and enhance the experience of online shopping, and obtain higher customer satisfaction, this paper introduced QFD into the online service feature recognition to realize the purpose of transforming the customer's demand into online service quality. Firstly, the online shopping service blueprint can effectively identify any key points in service system, thus identify the five dimensions that affect the quality of online shopping service: web design, customer service, shop reputation, logistics system, physical quality. Then the author developed questionnaires considering the service blueprint. According to the survey results and data, the customer demand and quality requirements of online shopping are extracted and analyzed. Thirdly, the importance of customer demand is determined by fuzzy comprehensive analysis. Finally, the relation matrix transformation method is used to determine the relationship matrix between customer demand and the online shopping service quality, and determine the importance degree of online service quality, thereby building the "customer demand - online shopping service quality" quality house. The service indicators, "improve product quality", "improve service efficiency", "improve the overall capacity of customer service", "optimize the logistics system" etc. have a high degree of importance, making businesses more targeted to improve their service system and get higher customer satisfaction, so as to enhance the quality of online shopping service. The empirical results show that the questionnaire designed is effective according to the service blueprint, and the method of using QFD to convert customer demand into service quality is feasible.
\end{abstract}

\section{INTRODUCTION}

Famous quality management master Juran had put forward that productivity is the key to the development of the 20th century and quality is the key to the development of the 21st century. With the development of the times and the progress of science and technology, people's demand for quality is getting higher and higher. At the present stage of accomplishing the first hundred years' struggle goal of the Chinese nation, people's living conditions have been greatly improved. On the basis of material security, people have put forward higher demands on service quality, the proportion of service economy in society is also increasing. At present, China's online shopping sales volume in the world is the first, but the quality needs to be improved. Therefore, in order to improve the quality of online shopping service, and give online shopping business targeted recommendations, and obtain higher customer satisfaction, enhance the competitiveness of enterprises, this paper on the quality of online shopping service research.

\section{THEORETICAL BASIS}

The quality of service is the result of the comparison between customer's expectation of service and the actual service, which is a scale to measure the level of service (Guangying Xie,2016). Nowadays, the demand for service quality in all walks of life is higher and higher. For shopping online, high-quality service will also be one of the core competencies of online merchants. Online shopping is the process of enterprise and customer trading via the Internet, at present, China's retail industry with the entity shop management, store management, combines two forms of multi-channel the stores and shop operation three forms coexist(Chatterjee P. Multiple-Channel,2010).The general process of online shopping: search for goods, compare the information, view reviews, online payment, logistics and transportation and so on, involving more aspects, leading to customer dissatisfaction factors are corresponding, so identify the key quality of service characteristics to improve the customer Satisfaction is important.

At this stage, the quality of service is crucial for every enterprise. Online shopping as a new industry, a variety of technology is not yet mature, a variety of systems is not perfect, making the quality of online shopping service research progress is relatively slow, and still in the initial stage of the study(Muhammad N S, Sujak H,2016).For the study of service quality, Parasuranman et al. proposed the SERVQUAL evaluation model to evaluate the quality of service(Gaoshan Wang,2014), which has become one of the basic methods for evaluating the quality of service. But the SERVQUAL evaluation model is actually measuring customer satisfaction, can't transform fuzzy customer requirements into quality features. WANG Wei-jun, TANG Lu et al. research on the method of language evaluation information in group decision-making theory to evaluate the quality of mobile e-commerce service (Weijun Wang,2017); Yan Wei, He Zhen et al. use the improved information gain algorithm to evaluate the standard to reduce the influence of bias in the unbalanced data, so as to effectively identify the key quality characteristics (Wei Yan,2012). Customers' needs are often vague and unspecific. In order to externalize the fuzzy requirements and translate the requirements of 
service quality to identify key service quality characteristics, this paper chooses the QFD method to achieve the above objectives.

The basic principle of the quality function is to convert the customer's needs into the products or services of customer needs. In other words, through the questionnaire, collect customer information and customer needs, and then sort the customer needs, the results will be as the input information of quality function deployment (QFD), after customer needs are identified, to convert customer requirements for quality, technical requirements and production quality control method, As well as the production quality control method, the establishment of customer needs and quality characteristics, technical requirements and production quality control methods such as the relationship between the matrix to determine the reliability of quality characteristics, The finally output of a satisfactory customer needs products or services(Lingling Lai,2017).

\section{MODEL CONSTRUCTION ON CRITICAL TO QUALITY OF ONLINE SHOPPING SERVICES BASED ON QFD}

In the process of constructing the model, firstly, the customer demand is obtained, and the customer demand is sorted by the affinity graph $(\mathrm{KJ})$ method. Secondly, the fuzzy comprehensive evaluation method is used to determine the importance of the customer demand. Finally, the relationship matrix is used to convert the customer demand Convert to Quality of Service features.

\subsection{The quality room construction of online shopping service}

The core of the whole QFD process is the quality house, as shown in figure 1, the quality of basic structure is:(1) the left wall: customer requirements, described in the language of the customer customer requirement for the quality of online service; (2) right wall: peer competition ability evaluation matrix, standing in the customer's perspective, to the online shopping service merchants to meet customer demand evaluation; (3) ceiling: quality requirements of online shopping service, indicating the requirements of customers, and how to design online shopping service quality indicators; (4) room: relationship matrix, describing the relationship between customer demand and online service quality indicators; (5) basement: online shopping service quality evaluation matrix, which is the output part of the quality room, complete the transformation of "customer demand" to "how to do online business"; (6) roof: correlation matrix is the self-correlation between the recognition of online service quality indicators. The relationship between customer demand and service quality requirements can be obtained through the quality house.

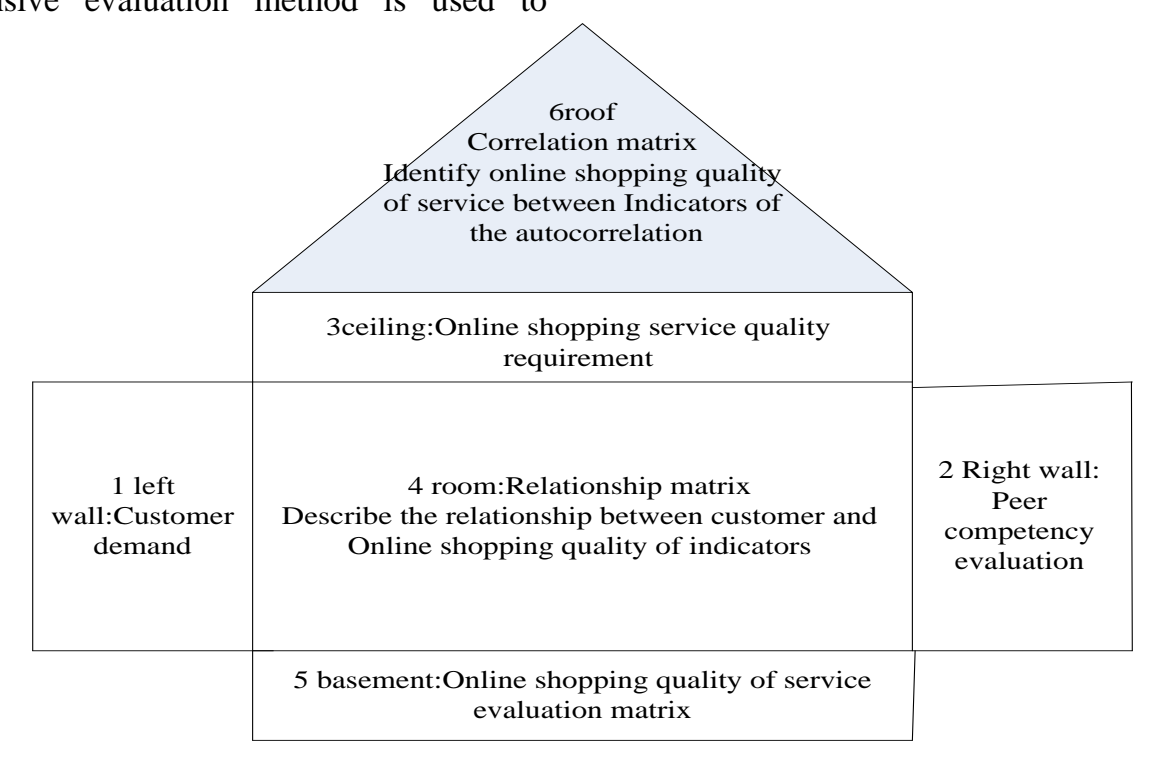

Figure 1 Online shopping service quality house

\subsection{Extraction and analysis of customer demand}

Generally, in the process of extraction and analysis of customer needs, we have inspect the information collection method, evaluation method of the importance degree based on neural network QFD customer demand, personalized customer demand described method (Li Chen,2013). This paper uses the service blueprint to extract and analyze customer demand from the perspective of customers. Founder of the concept of the service blueprint Lynn · shustark: the service blueprint is a detailed planning and analytical files, in the form of flow chart to illustrate the process of service and details.
In essence, the service blueprint is to analyze the processes that constitute the entire service system in the form of charts (Jay. Kandampli,2006). As shown in Figure 2, from the customer's point of view, draw a blueprint for online shopping services. Through the service blueprint and the customer's point of view to develop a questionnaire. Through the questionnaire and small-scale interviews to collect the original data is complex and different, so the affinity (KJ) method is used to organize customer needs, and get the customer needs to expand the table, as shown in Table 1. 
Table 1 Online shopping service customer needs to expand the table

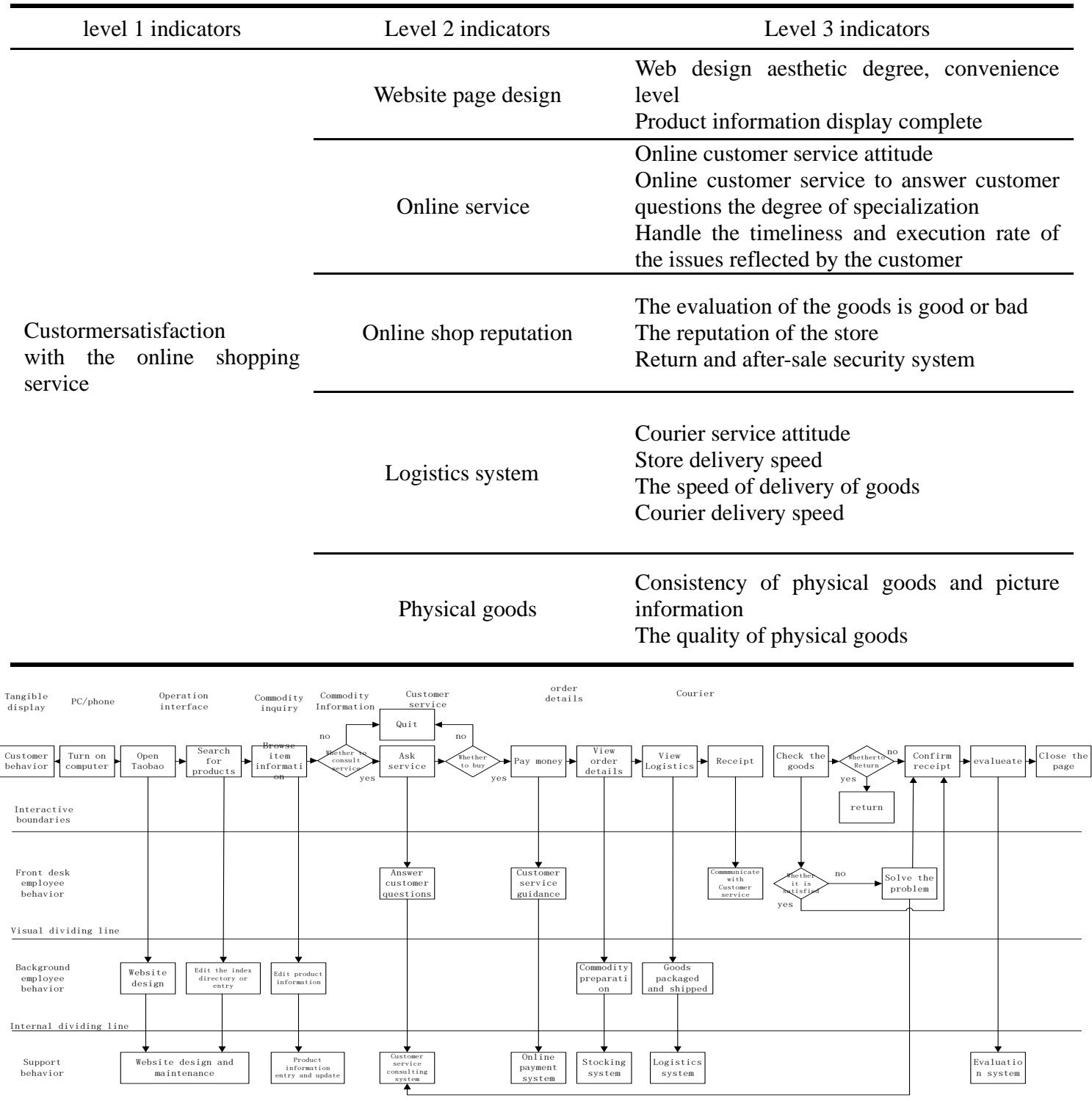

Figure 2 Online shopping service blueprint

\subsection{Determination of customer demand importance based on fuzzy comprehensive evaluation method}

After the customer's needs have been determined, we should determine which needs of the customer is the most important, so it should give these needs a proper sort. This paper makes use of fuzzy comprehensive analysis to order the importance of customer demand (Fengmei Zhu,2016).

\subsubsection{Determine the set of evaluation factors}

The evaluation system used in this paper consists of five first-level indicators and corresponding 12 secondary indicators. Level $1: U=\left\{\right.$ web design $\left(U_{1}\right)$, customer service $\left(U_{2}\right)$, shop reputation $\left(U_{3}\right)$, logistics system $\left(U_{4}\right)$, physical quality $\left.\left(U_{5}\right)\right\}$; secondary indicators: $U_{1}=\{$ beautiful and convenient, complete information $\} ; U_{2}$

$=\{$ customer service response Speed, customer service specialization, customer service attitude, customer feedback problem processing $\}$;

$U_{3}=\{$ commodity evaluation, after-sale protection $\}$;
$U_{4}=\{$ courier service quality, parcel delivery speed $\}$;

$U_{5}=\{$ product quality, product consistency degree $\}$.

\subsubsection{To determine the weight of the indicators}

Using the Delphi method, select the seven experts to score, take the average value of the primary and secondary weights.

\subsubsection{To establish a fuzzy relationship matrix}

$$
R=\left(r_{i j}\right)_{m \times n}, i=(1,2,3, \cdots, n), j=(1,2,3, \cdots, m)
$$

Indicates the degree of membership of the online purchase customer's evaluation grade of indicator

\subsubsection{Multi-level fuzzy comprehensive evaluation}

For each index Ui according to the evaluation level V, the weight vector Aithe evaluation matrix Rifor a fuzzy evaluation, obtained $B_{i}=A_{i} \circ R_{i}=\left\{\begin{array}{llll}b_{i 1} & b_{i 2} & \cdots & b_{i m}\end{array}\right\}$.The primary evaluation results bi as a secondary evaluation factor set, the two comprehensive evaluation. $\mathrm{B}$ is normalized and evaluted according to the principle of maximum 
membership.

\subsubsection{Calculate the index scores}

In order to make the results more clear and intuitionistic, the index score of satisfaction was calculated based on the grading method. The five levels of evaluation are divided into: $D=\left\{\begin{array}{lllll}d_{1} & d_{2} & d_{3} & d_{4} & d_{5}\end{array}\right\}=\left\{\begin{array}{lllll}100 & 80 & 60 & 40 & 20\end{array}\right\}$. The final score calculation formula is

$$
F=100 r_{i 1}+80 r_{i 2}+60 r_{i 3}+40 r_{i 4}+20 r_{i 5}
$$

\subsection{Establish the relationship between online shopping service characteristics and customer demand matrix}

The relationship matrix is a bridge between customer needs and quality requirements, and is one of the most important components of a quality house. This part describes the correlation between customer demand and service indicators, there are irrelevant, weak correlation, medium correlation and strong correlation of four kinds of association strength. With different symbols or values to represent the characteristics of online shopping service quality and customer relationship between the degree of strength and strength (as shown in Table 2). In general, () indicates the strong correlation between the quality characteristics of online shopping service and customer demand; $\odot$ represents the intermediate relationship between the quality of online shopping service and the customer demand; in terms of, $\bigcirc$ the relationship between online shopping service and customer demand is weak; use $\times$ to express the relationship between online shopping service characteristics and customer demand

Table 2 Example of relation matrix

\begin{tabular}{|c|c|c|c|c|c|c|c|c|c|}
\hline $\begin{array}{l}\text { Quality of } \\
\text { Service Features }\end{array}$ & $\begin{array}{l}\text { Demand } \\
\text { element } \\
\text { importance }\end{array}$ & $\begin{array}{l}\text { Quality } \\
\text { of } \\
\text { Service } \\
\text { Features } \\
1\end{array}$ & $\begin{array}{l}\text { Quality } \\
\text { of } \\
\text { Service } \\
\text { Features } \\
2\end{array}$ & $\begin{array}{l}\text { Quality } \\
\text { of } \\
\text { Service } \\
\text { Features } \\
3\end{array}$ & $\begin{array}{l} \\
\ldots \\
\cdots\end{array}$ & $\begin{array}{l}\text { Quality of } \\
\text { Service } \\
\text { Features } \\
\text { n-1 }\end{array}$ & $\begin{array}{l}\text { Quality } \\
\text { of } \\
\text { Service } \\
\text { Features } \\
\mathrm{n}\end{array}$ & $\begin{array}{l}\text { Market } \\
\text { Competitive } \\
\text { Evaluation of } \\
\text { Online Shopping } \\
\text { Service } \\
\text { Organization }\end{array}$ & Plan goals \\
\hline $\begin{array}{l}\text { Demand element } 1 \\
\left(N_{1}\right)\end{array}$ & & $x$ & (2) & $x$ & & (2) & O & & \\
\hline $\begin{array}{l}\text { Demand element } 2 \\
\left(N_{2}\right)\end{array}$ & & $x$ & 0 & O & & $\odot$ & $x$ & & \\
\hline$\vdots$ & & & & & & & & & \\
\hline $\begin{array}{l}\text { Demand element } \mathrm{n} \\
\left(N_{n}\right)\end{array}$ & & (2) & $x$ & O & & (2) & $\odot$ & & \\
\hline $\begin{array}{l}\text { Service characteristic } \\
\text { Absolute importance }\end{array}$ & & & & & & & & & \\
\hline $\begin{array}{l}\text { The relative importance of } \\
\text { service characteristics }\end{array}$ & & & & & & & & & \\
\hline $\begin{array}{l}\text { Evaluation of Technology } \\
\text { Competitiveness of Online } \\
\text { Shopping Service } \\
\text { Organization }\end{array}$ & & & & & & & & & \\
\hline Target value & & & & & & & & & \\
\hline
\end{tabular}

\subsection{The transformation method of requirement importance degree}

Relationship matrix transformation method

(1) the calculation of the absolute importance of service characteristics

Absolute weight of service characteristics = customer demand importance $\mathrm{x}$ customer demand importance and service characteristics of the relationship between the intensity. For this reason, the relationship between the importance of customer demand and the relationship between the service characteristics of the strength of the assignment, if the $(0=9, \odot=3, \circ=1, \times=0$, the service characteristics of the absolute weight calculation method is as follows ( $W_{i}$ represents the absolute importance of the $i$ service feature):

$$
\begin{aligned}
& W_{1}=N_{1} \bullet \mathrm{X}+N_{2} \bullet \mathrm{X}+N_{3} \bullet \square+\cdots+N_{n-1} \bullet \mathrm{X}+N_{n} \bullet \square \\
&=N_{1} \bullet 0+N_{2} \bullet 0+N_{3} \bullet 3+\cdots+N_{n-1} \bullet 0+N_{n} \bullet 9 \\
& W_{2}=N_{1} \bullet \square+N_{2} \bullet \mathrm{X}+\mathrm{N}_{3} \bullet \mathrm{X}+\cdots+N_{n-1} \bullet \mathrm{X}+N_{n} \bullet \mathrm{O} \\
&=N_{1} \bullet 9+N_{2} \bullet 0+N_{3} \bullet 0+\cdots+N_{n-1} \bullet 0+N_{n} \bullet 1 \\
& W_{3}=N_{1} \bullet \mathrm{X}+N_{2} \bullet \square+N_{3} \bullet \mathrm{O}+\cdots+N_{n-1} \bullet \mathrm{X}+N_{n} \bullet \mathrm{X} \\
&=N_{1} \bullet 0+N_{2} \bullet 9+N_{3} \bullet 1+\cdots+N_{n-1} \bullet 0+N_{n} \bullet 0
\end{aligned}
$$

$$
\begin{aligned}
W_{n-1} & =N_{1} \bullet \square+N_{2} \bullet \mathrm{X}+\mathrm{N}_{3} \bullet \mathrm{X}+\cdots+\mathrm{N}_{\mathrm{n}-1} \bullet \Theta+N_{n} \bullet \mathrm{X} \\
& =N_{1} \bullet 9+N_{2} \bullet 0+N_{3} \bullet 0+\cdots+N_{n-1} \bullet 3+N_{n} \bullet 0 \\
W_{n}= & N_{1} \bullet \mathrm{O}+N_{2} \bullet \mathrm{X}+N_{3} \bullet \mathrm{X}+\cdots+N_{n-1} \bullet \mathrm{X}+N_{n} \bullet \mathrm{O} \\
= & N_{1} \bullet 1+N_{2} \bullet 0+N_{3} \bullet 0+\cdots+N_{n-1} \bullet 0+N_{n} \bullet 1
\end{aligned}
$$

(2) The calculation of the relative importance of service characteristics

Different dimensions of the evaluation index is different from the dimension unit of the evaluation index, and the difference of the dimension unit has a great influence on the result of the analysis data. In order to eliminate the difference between the different indicators, making the data indicators are comparable between the service characteristics of the importance of the data to be standardized. Using $D W_{i}$ to represent the relative importance of the $\mathrm{i}$ online shopping service quality characteristics, the relative importance of the online shopping service quality characteristics can be expressed as follows:

$$
D W_{1}=W_{1} / \sum_{i=1}^{n} W_{i} \bullet 100
$$




$$
\begin{gathered}
D W_{2}=W_{2} / \sum_{i=1}^{n} W_{i} \bullet 100 \\
D W_{n-1}=W_{n-1} / \sum_{i=1}^{n} W_{i} \bullet 100 \\
D W_{n}=D W_{n} / \sum_{i=1}^{n} W_{i} \bullet 100
\end{gathered}
$$

\section{EMPIRICAL ANALYSIS}

\subsection{The data analysis}

In this study, Zhengzhou College students conducted a questionnaire survey, using online research and face-to-face research combined approach. A total of 100 questionnaires were issued, 73 valid questionnaires were retrieved. Questionnaire using the five-level scoring system, the degree of customer satisfaction of the online shopping process from low to high is divided into \{very important, not important, general, important, very important $\}$ five grades, the corresponding level of each score converted to $\{1,2,3,4,5\}$. The results of the

\begin{tabular}{|c|c|c|c|c|c|c|}
\hline $\begin{array}{l}\text { level } 1 \text { indicators } \\
\text { important }\end{array}$ & Level 2 indicators & very important & important & general & not important & very not \\
\hline \multirow[t]{2}{*}{ Web Design } & Beautiful and convenient & $14(18.91 \%)$ & $42(56.76 \%)$ & $13(17.57 \%)$ & $2(2.7 \%)$ & $3(4.05 \%)$ \\
\hline & Information is complete & $32(43.24 \%)$ & $35(47.30 \%$ & $4(5.4 \%)$ & $2(2.7 \%)$ & $1(1.35 \%)$ \\
\hline \multirow[t]{4}{*}{ Staff service } & Staff response speed & $24(32.43 \%)$ & $33(44.60 \%)$ & $13(17.57 \%)$ & $2(2.7 \%)$ & $2(2.7 \%)$ \\
\hline & Staff service specialization & $20(27.02 \%)$ & $38(51.35 \%)$ & $15(20.27 \%)$ & $0(0 \%)$ & $1(1.35 \%)$ \\
\hline & Staff service attitude & $26(35.13 \%)$ & $38(51.35 \%)$ & $9(12.16 \%)$ & $0(0 \%)$ & $1(1.35 \%)$ \\
\hline & Staff feedback problem processing & $26(35.13 \%)$ & $42(56.76 \%)$ & $5(6.76 \%)$ & $0(0 \%)$ & $1(1.35 \%)$ \\
\hline \multicolumn{2}{|c|}{ Online shop reputation Product review } & $26(35.13 \%)$ & $37(50 \%)$ & $7(9.46 \%)$ & $3(4.05 \%)$ & $1(1.35 \%)$ \\
\hline & After-sale warranty & $28(37.84 \%)$ & $35(47.30 \%)$ & $8(10.81 \%)$ & $2(2.7 \%)$ & $1(1.35 \%)$ \\
\hline \multirow[t]{2}{*}{ Logistics system } & Courier service quality & $10(13.51 \%)$ & $21(28.38 \%)$ & $36(48.65 \%)$ & $6(8.11 \%)$ & $1(1.35 \%)$ \\
\hline & Parcel delivery speed & $20(27.02 \%)$ & $31(41.89 \%)$ & $20(27.02 \%)$ & $2(2.7 \%)$ & $1(1.35 \%)$ \\
\hline \multirow[t]{2}{*}{ Product quality } & Product quality & $45(60.81 \%)$ & $26(35.13 \%)$ & $2(2.7 \%)$ & $0(0 \%)$ & $1(1.35 \%)$ \\
\hline & Commodity consistency & $39(52.7 \%)$ & $30(40.54 \%)$ & $4(5.41 \%)$ & $0(0 \%)$ & $1(1.35 \%)$ \\
\hline
\end{tabular}
questionnaire are shown in Table 3.

Table 3 Questionnaire results

In this study, statistical analysis was performed using spss21.0. Calculate the Cronbach's a coefficient. The results of the questionnaire showed that the Cronbach's alpha coefficient of the questionnaire was $0.888>0.7$, and the internal consistency of the questionnaire was better, indicating that the questionnaire had higher reliability.

\subsection{Analysis of the importance of customer demand based on fuzzy comprehensive evaluation method}

The customer needs based on QFD can be sorted into five first-level indicators and 12 second-level indicators: web design (beautiful and convenient, complete information), staff service (staff service response speed, customer service specialization), staff service attitude (Product quality, product quality, product consistency degree), the quality of the goods (quality of goods, product consistency). Each item is very important (5 points), important (4 points), general (3 points), not important (2 points), very important (1 point) 5 evaluation level.

According to the results of Table 3 , and using the Delphi method, select the seven experts to score, take the average calculation of the weight of indicators:

Primary index weight

$$
A=\left\{\begin{array}{lllll}
0.1407 & 0.2 & 0.2370 & 0.1630 & 0.2590
\end{array}\right\} ;
$$

The secondary index weights are:

$$
\begin{aligned}
\text { A1 } & =\left\{\begin{array}{ll}
0.0623 & 0.0781
\end{array}\right\} \\
\text { A2 } & =\left\{\begin{array}{llll}
0.0721 & 0.0885 & 0.0820 & 0.0885
\end{array}\right\} \\
\text { A3 } & =\left\{\begin{array}{ll}
0.0885 & 0.0885
\end{array}\right\}
\end{aligned}
$$

$$
\begin{aligned}
& \text { A4 }=\left\{\begin{array}{ll}
0.0689 & 0.0787
\end{array}\right\} \\
& \text { A5 }=\left\{\begin{array}{ll}
0.0885 & 0.1148
\end{array}\right\}
\end{aligned}
$$

According to the survey results to establish a fuzzy matrix:

$$
\begin{aligned}
\mathrm{R}_{1} & =\left[\begin{array}{lllll}
0.1891 & 0.5676 & 0.1757 & 0.0270 & 0.0405 \\
0.4324 & 0.4730 & 0.0540 & 0.0270 & 0.0135
\end{array}\right] \\
\mathrm{R}_{2} & =\left[\begin{array}{llllll}
0.3243 & 0.4460 & 0.1757 & 0.0270 & 0.0270 \\
0.2702 & 0.5135 & 0.2027 & 0 & 0.0135 \\
0.3513 & 0.5135 & 0.1216 & 0 & 0.0135 \\
0.3513 & 0.5676 & 0.0676 & 0 & 0.0135
\end{array}\right] \\
\mathrm{R}_{3} & =\left[\begin{array}{llllll}
0.3513 & 0.5 & 0.0946 & 0.0405 & 0.0135 \\
0.3784 & 0.4730 & 0.1081 & 0.027 & 0.0135
\end{array}\right] \\
& =\left[\begin{array}{llllll}
0.1351 & 0.2838 & 0.4865 & 0.0811 & 0.0135 \\
0.2702 & 0.4189 & 0.2702 & 0.0270 & 0.0135
\end{array}\right] \\
\mathrm{R}_{5} & =\left[\begin{array}{llllll}
0.6081 & 0.3513 & 0.0270 & 0 & 0.0135 \\
0.5270 & 0.4054 & 0.0541 & 0 & 0.0135
\end{array}\right]
\end{aligned}
$$

According to $B_{i}=A_{i} \circ R_{i}=\left\{\begin{array}{llll}b_{i 1} & b_{i 2} & \cdots & b_{i m}\end{array}\right\}$, the comprehensive evaluation vector is obtained, and the single factor fuzzy evaluation is obtained for each index.

$$
\left[\begin{array}{l}
B_{1} \\
B_{2} \\
B_{3} \\
B_{4} \\
B_{5}
\end{array}\right]=\left[\begin{array}{lllll}
0.0781 & 0.0781 & 0.0623 & 0.0270 & 0.0405 \\
0.0885 & 0.0885 & 0.0885 & 0.0270 & 0.020 \\
0.0885 & 0.0885 & 0.0885 & 0.0405 & 0.0135 \\
0.0689 & 0.0787 & 0.0787 & 0.0689 & 0.0135 \\
0.1148 & 0.1148 & 0.0541 & 0 & 0.0135
\end{array}\right]
$$

Create a two-level fuzzy matrix: 


$$
R=\left[\begin{array}{lllll}
0.0781 & 0.0781 & 0.0623 & 0.0270 & 0.0405 \\
0.0885 & 0.0885 & 0.0885 & 0.0270 & 0.020 \\
0.0885 & 0.0885 & 0.0885 & 0.0405 & 0.0135 \\
0.0689 & 0.0787 & 0.0787 & 0.0689 & 0.0135 \\
0.1148 & 0.1148 & 0.0541 & 0 & 0.0135
\end{array}\right]
$$

Combined with the weight of primary indicators to calculate the satisfaction of the comprehensive evaluation results

$\mathrm{B}=\left[\begin{array}{lllll}0.2685 & 0.2685 & 0.2070 & 0.1612 & 0.0947\end{array}\right]$, according to the maximum degree of membership to $b_{1}=b_{2}=0.2685$, we can see that the above service indicators are important for customer satisfaction.

According to the formula 1: $F=100 r_{i 1}+80 r_{i 2}+60 r_{i 3}+40 r_{i 4}+20 r_{i 5}$, calculate the page design, customer service, shop reputation, logistics system, physical quality of customer satisfaction degree of score were 19.683,22.72,23.13,20.934,24.18.

By the above data can concluded that the key factors influencing the online shopping service quality according to the important degree of order from big to small order is physical quality, shop reputation, customer service, logistics systems, web design.

\subsection{Establish a relationship matrix between customer needs and service indicators}

Customer demand is determined by the service blueprint and the questionnaire, the customer demand in the expression are more colloquial. Before establishing a relationship matrix, it is necessary to convert colloquial, abstract and vague customer needs into concrete, enforceable and measurable service metrics. The correct and effective service indicators can meet the needs of customers, service indicators due to industry or the types of services provided by the different, this article through small-scale interviews and access to literature will be online shopping service indicators extracted, the results shown in Table 4 Show.

Table 4 Service Indicators

\begin{tabular}{|c|c|c|}
\hline Level 1 indicators & Level 2 indicators & Level 3 indicators \\
\hline & $\begin{array}{l}\text { Reasonable, user-friendly web } \\
\text { design }\end{array}$ & $\begin{array}{l}\text { Web design nice, easy to operate } \\
\text { Product information display complete }\end{array}$ \\
\hline & Reasonable staffing & $\begin{array}{l}\text { Online staff service attitude is good } \\
\text { Online staff service to answer customer } \\
\text { questions with a high degree of specialization }\end{array}$ \\
\hline & Improve service efficiency & $\begin{array}{l}\text { Timely response to customers } \\
\text { Store's high reputation level } \\
\text { Timely and properly handle the customer's } \\
\text { questions }\end{array}$ \\
\hline
\end{tabular}

Customer satisfaction with the online shopping service
Improve the overall capacity of staff service
Online staff service to answer customer questions with a high degree of specialization Timely and properly handle the customer's questions

\begin{tabular}{ll}
\hline Improve the relevant system & $\begin{array}{l}\text { Return and after-sale security system sound } \\
\text { The number of praise for the goods }\end{array}$ \\
\hline Optimize the logistics system & $\begin{array}{l}\text { Courier service attitude is good } \\
\text { Store delivery speed } \\
\text { The delivery of goods is fast } \\
\text { Courier delivery speed }\end{array}$ \\
\hline improve product quality & $\begin{array}{l}\text { Physical goods and picture information } \\
\text { consistency } \\
\text { The quality of physical goods is high }\end{array}$
\end{tabular}

The relationship between customer demand and service index is not a purely functional relationship. Therefore, the relationship between customer demand and service index is expressed by correlation degree and the correlation matrix is constructed. In the process of constructing the relation matrix, the customer demand and the service index are established according to the correlation level of strong correlation (○), medium degree correlation $(\odot)$, weak correlation $(\circ)$ and irrelevant $(\times)$. The matrix is the quality of the room and is an important part of building a quality hous.

\subsection{Customer demand and service indicators of the importance of conversion}

The important degree of customer demand in this study is that the web design is beautiful and convenient (7.8\%), product information is complete $(8.7 \%)$, quickly response to customers (8.1\%),answer questions professional (8.2\%),good service attitude (8.5\%),Product evaluation and more(8.4\%),courier service quality is 
good (7\%), goods transport fast (7.9\%), have a reliable after-sale protection (8.5\%), timely processing of customers to reflect the problem (8.6\%),merchandise and store description (9\%),good quality goods (9.2\%).

Therefore, firstly, the correlation degree of the relational matrix is assigned, and the importance of the service index is finally obtained through the calculation of the importance degree of the customer demand. In the conversion process, the values of $\odot$, $\odot, \circ$ are given to the value of the calculation, so that: $\odot: \circ=5: 3: 1$, the degree of customer demand is multiplied by the intensity of each row. And the importance of the service indicators is shown in Table 5.

Table 5 Customer Demand Importance Conversion Table

\begin{tabular}{|c|c|c|c|c|c|c|c|c|}
\hline \multicolumn{2}{|l|}{$\begin{array}{l}\text { Service indicators } \\
\text { Customer demand }\end{array}$} & \multirow{2}{*}{$\begin{array}{l}\text { Reasonable, } \\
\text { user - } \\
\text { friendly web } \\
\text { design }\end{array}$} & \multirow[t]{2}{*}{$\begin{array}{l}\text { Reasonable } \\
\text { staffing }\end{array}$} & \multirow[t]{2}{*}{$\begin{array}{l}\text { Improve } \\
\text { service } \\
\text { efficiency }\end{array}$} & \multirow{2}{*}{$\begin{array}{l}\text { Improve the } \\
\text { overall } \\
\text { capacity of } \\
\text { customer } \\
\text { service }\end{array}$} & \multirow[t]{2}{*}{$\begin{array}{l}\text { Improve } \\
\text { the } \\
\text { relevant } \\
\text { system }\end{array}$} & \multirow{2}{*}{$\begin{array}{l}\text { Optimize } \\
\text { the } \\
\text { logistics } \\
\text { system }\end{array}$} & \multirow[t]{2}{*}{$\begin{array}{l}\text { Improve } \\
\text { product } \\
\text { quality }\end{array}$} \\
\hline Demand layer & Importance & & & & & & & \\
\hline $\begin{array}{l}\text { Web design } \\
\text { convenient and } \\
\text { beautiful }\end{array}$ & 0.078 & () & $\circ$ & ० & $x$ & $x$ & $x$ & $x$ \\
\hline $\begin{array}{l}\text { Product information } \\
\text { is complete }\end{array}$ & 0.087 & (a) & $x$ & $\odot$ & $x$ & $x$ & $x$ & $x$ \\
\hline $\begin{array}{l}\text { Quickly response to } \\
\text { customers }\end{array}$ & 0.081 & $x$ & $\circ$ & $\odot$ & $\circ$ & $x$ & $x$ & $x$ \\
\hline $\begin{array}{l}\text { answer questions } \\
\text { professional }\end{array}$ & 0.082 & $x$ & $\circ$ & $\odot$ & $\odot$ & $x$ & $x$ & $x$ \\
\hline Good service attitude & 0.085 & $x$ & 0 & $\odot$ & (2) & $x$ & $x$ & $x$ \\
\hline $\begin{array}{l}\text { Product evaluation } \\
\text { and more }\end{array}$ & 0.084 & $\circ$ & $x$ & $x$ & $x$ & $\circ$ & (0) & (2) \\
\hline $\begin{array}{l}\text { Courier service } \\
\text { quality is good } \\
\end{array}$ & 0.070 & $x$ & $\circ$ & $x$ & $\odot$ & $x$ & $\odot$ & $x$ \\
\hline Goods transport fast & 0.079 & $x$ & $x$ & (2) & $x$ & $x$ & (2) & $x$ \\
\hline $\begin{array}{l}\text { Have a reliable } \\
\text { after-sales protection }\end{array}$ & 0.085 & $x$ & $\times$ & $\odot$ & $x$ & (2) & $x$ & $x$ \\
\hline $\begin{array}{l}\text { Timely processing of } \\
\text { customers to reflect } \\
\text { the problem }\end{array}$ & 0.086 & $x$ & (a) & $\odot$ & (2) & $\odot$ & $x$ & $x$ \\
\hline $\begin{array}{l}\text { Merchandise and } \\
\text { store description }\end{array}$ & 0.090 & $x$ & $x$ & $x$ & $x$ & $x$ & $x$ & (a) \\
\hline Good quality goods & 0.092 & $x$ & $x$ & $x$ & $x$ & $x$ & $x$ & (2) \\
\hline $\begin{array}{l}\text { Absolute importance } \\
\text { of service indicators }\end{array}$ & 12.5 & 0.909 & 0.396 & 1.991 & 1.392 & 0.767 & 1.11 & 5.47 \\
\hline $\begin{array}{l}\text { The relative } \\
\text { importance of service } \\
\text { indicators }\end{array}$ & 100 & 7.3 & 6.6 & 16 & 11.2 & 6.1 & 8.9 & 43.9 \\
\hline
\end{tabular}

\subsection{Suggestions for Improvement}

Through data show that the critical to quality of service important degrees from big to small in turn is: improve the quality of our products (43.9\%), improve the service efficiency (16\%), improve the ability of the personnel of the service as a whole (11.2\%), optimization of logistics system (8.9\%), reasonable humanized web design (7.3\%), the reasonable manning (6.6\%), a sound system of related (6.1\%). The following Suggestions are put forward according to the above data to improve online shopping service quality:

(1) Improve product quality

Whether it is online shopping or physical store shopping, getting the practical goods is the ultimate goal of consumers, so that meet their own consumer desire. If the quality of goods is not good, no matter how good the service industry can not meet customer needs. High-quality goods can not only satisfy the customers themselves, but also improve the reputation of the store with the praise of customers, so that more consumers can purchase the goods. Therefore, the online seller should strengthen the control of the quality of goods. At the same time, pay attention to reduce the cost of goods.

(2) Improve service efficiency and service ability

The service efficiency of online shopping is largely related to online staff service. The only person who can communicate with consumers during online shopping is online staff. Online staff should have a deep understanding of the whole process of online shopping, product information and logistics problems, so that improve their service level, improve their comprehensive ability. Good communication with customers, reassure customers and eliminate doubts can improve the service efficiency.

(3) Optimize the logistics system

The biggest difference between online shopping and traditional shopping is that online shopping consumers can not get goods immediately, so the goods that can be delivered to customers in a short period of time can improve customer satisfaction. Stores can increase their delivery speed, and choose guaranteed delivery companies to transport goods to customers at the fastest speed.

\section{CONCLUSIONS}

This paper obtains the online service of customer demand, and calculates the important degree of customer requirements by using fuzzy comprehensive analysis method, builds the house of online service quality and converts customer requirements to quality requirements. Through the empirical study, the key factors that affect 
the quality of online shopping service are identified: attach importance to product quality, improve the service efficiency and the comprehensive ability of the service, optimize the logistics system and so on, these factors make the business improve their service system more targeted, and obtain a higher customer satisfaction. In the process of building quality house in this paper, the selection of indicators is partial to subjectivity. Hope to find a way to avoid the subjective factors in the future, and continue to study the critical to quality of online shopping service.

\section{REFERENCES}

[1] Guangying Xie. B2C and C2C online shopping logistics quality of service evaluation: A Conceptual Model and Theoretical Framework [J]. Management Review, 2016,28(4): 186-200.

[2] Chatterjee P. Multiple-Channel and Cross-Channel Shopping Behavior[J]. Marketing Intelligence \& Planning, 2010, 28(1): 9-24

[3] Muhammad N S, Sujak H, Rahman S A. Buying Groceries Online: The Influences of Electronic Service Quality
(eServQual) and Situational Factors[J]. Procedia Economics \& Finance,2016,37:379-385.

[4] Gaoshan Wang, Tao Yu, Xin Zhang. The impact of electronic service quality on users' continued use: Customer Intervention Effect [J]. Management Review, 2014, 26 (10): 126-137.

[5] Weijun Wang, Lu Tang, Yinxiu Hou, et al. Research on Quality Evaluation of Mobile E-commerce Based on Language Evaluation Information [J]. Library and Information Service, 2017 (4): 83-89.

[6] Wei Yan, Zhen He, Wenmeng Tian. Identification of key quality characteristics of complex products [J]. Industrial Engineering, 2012, 15 (3): 75-79.

[7] Lingling Lai, Ning Tang, Lifang Peng. Based on QFD online travel electronic service quality improvement research [J]. Mathematical practice and understanding, 2017,47 (16): 20-30.

[8] Li Chen, Peihua Liu, Zhe Xu. Research on Customer Demand Acquisition Method in Service Design and Its Application in Library Service System [J]. Library and Information Work, 2013 (s1): 232-236.

[9] Jay. Kandampli. Service Management: A New Model of Hotel Management [M]. Tourism Education Press, 2006.

[10] Fengmei Zhu. Research on Evaluation of Medicaland Health System Reform Based on Fuzzy Comprehensive Evaluation Method [J]. Chinese Journal of Health Statistics, 2016, 33 (2): 267-27 